\title{
ANALISIS PENGARUH KUALITAS PELAYANAN TERHADAP TINGKAT LOYALITAS PASIEN RAWAT JALAN DI RS. X SURABAYA
}

\author{
Puryanti $^{1)}$, Muhadi ${ }^{2}$ \\ Program Studi Administrasi Rumah Sakit, STIKES Yayasan RS. Dr. Soetomo \\ email: puryanti@stikes-yrsds.ac.id
}

\begin{abstract}
Abstrak
Jumlah kunjungan pasien rawat jalan merupakan salah satu indikator kinerja pelayanan rawat jalan di rumah. Jumlah kunjungan pasien rawat jalan di Rumah Sakit X selama tiga tahun terakhir tahun 20162018 mengalami penurunan sebesar 10\%. Tujuan penelitian ini untuk menganalisis pengaruh kualitas pelayanan rawat jalan terhadap tingkat loyalitas pasien rawat jalan di Rumah Sakit X. Jenis penelitian ini penelitian diskriptif analitik dengan rancang bangun penelitian cross sectional. Sampel penelitian ini adalah pasien rawat jalan sebesar 36 sampel dengan teknik accidental sampling. Analisis data menggunakan uji regresi linear berganda. Hasil penelitian menujukkan bahwa kualitas pelayanan dokter, perawat, petugas pendaftaran sudah baik (mean $\geq 3,00$ ). Kualitas sarana prasarana kurang baik (mean < 3,00). Tingkat loyalitas pasien berada pada level kesediaan untuk menggunakan kembali dan belum sampai pada level advocacy. Hasil uji regresi linier berganda menunjukkan kualitas pelayanan dokter dan petugas pendaftaran berpengaruh terhadap tingkat loyalitas pasien. Kualitas pelayanan perawat dan sarana prasarana tidak berpengaruh terhadap tingkat loyalitas pasien. Kesimpulan penelitian ini adalah secara keseluruhan kualitas pelayanan berpengaruh terhadap tingkat loyalitas pasien.
\end{abstract}

Kata kunci : kualitas, pelayanan, loyalitas, pasien

\begin{abstract}
The number of outpatient visits is one indicator of the performance of outpatient services in hospitals. The number of outpatient visit at Hospital X during the last three years in $2016-2018$ increased a decrease of $10 \%$. The purpose of this study was to analyze the influence of the quality of outpatient services on the level of outpatient loyalty at Hospital X. This was descriptive analytics research with cross-sectional design. The sample of this study was outpatients for 36 samples with accidental sampling technique. Data analysis uses multiple linear regression test. The result showed that the quality of the services of doctors, nurses, registration officers was good (mean $\geq 3,00$ ). The quality of infrastructure is poor (mean $<3,00$ ). The level of patient loyalty is at the level of willingness to use again and has not yet reached the level of advocacy. The results of multiple linear regression tests indicate the quality of the services of doctor and registration officers affect the level of patient loyalty. The quality of nurse services and facility does not affect the level of patient loyalty. The conclusion of this study is that overall service quality affects the level of patient loyalty.
\end{abstract}

Keywords : service, quality, loyalty, patients

\section{PENDAhULUAN}

Kunjungan pasien rawat jalan di sebuah rumah sakit merupakan sumber pangsa pasar bagi rumah sakit, karena jumlah kunjungannya jauh lebih besar dari kunjungan rawat inap. Dimasa mendatang jumlah kunjungan pasien rawat jalan diperkiraan mampu mengimbangi pendapatan pelayanan rawat inap rumah sakit. Jumlah kunjungan pasien rawat jalan juga dapat digunakan sebagai salah satu indikator kinerja pelayanan rawat jalan di rumah sakit. Ditengah persaingan rumah sakit yang semakin tinggi, Rumah sakit harus melakukan perubahan dan perbaikan secara terus menerus baik dari segi kualitas pelayanan maupun sarana prasarana. Kualitas pelayanan memiliki peran dalam membentuk tingkat loyalitas konsumen (Tjiptono, 2011).

Peningkatan kualitas pelayanan rumah sakit akan memberikan dampak pada kepuasan pasien. Pasien yang merasa puas dengan kualitas pelayanan yang diberikan rumah sakit akan mempengaruhi tingkat loyalitas pasien 
yaitu kesediaan pasien untuk menggunakan kembali pelayanan serta kesediaan untuk merekomendasikan kepada orang lain. Untuk meningkatkan kualitas pelayanan kepada pasien, harus diketahui bahwa layanan yang diberikan telah sesuai dengan harapan pasien atau belum (Mudjid, et al., 2018).

Rumah Sakit X merupakan rumah sakit khusus yang berlokasi di Kota Surabaya. Rumah Sakit $X$ sudah menjadi provider pelayanan BPJS kesehatan. Pelayanan kesehatan yang tersedia di Rumah Sakit X meliputi pelayanan rawat inap, pelayanan rawat jalan, pelayanan gawat darurat, serta pelayanan penunjang lainnya. Selama lima tahun terakhir rumah sakit telah berupaya meningkatkan kunjungan pasien baik di pelayanan rawat jalan dan pelayanan rawat inap. Salah satu upaya yang telah dilakukan oleh pihak rumah sakit untuk meningkatkan kunjungan adalah dengan menjadi provider BPJS.

Selain itu upaya yang dilakukan oleh Rumah Sakit X yaitu dengan meningkatkan kualitas pelayanan yang ada di rumah sakit baik dari segi sumber daya manusia, sarana prasarana dan manajemen rumah sakit. Rumah sakit berharap dengan meningkatkan kualitas pelyanan dapat meningkatkan kunjungan dan loyalitas pasien. Mutu pelayanan kesehatan memberikan efek kepada keinginan pasien untuk kembali memanfaatkan pelayanan kesehatan di rumah sakit. Ada beberapa tingkatan loyalitas pasien mulai dari tingkat loyalitas rendah sampai tingkat loyalitas dimana pasien bersedia menjadi advocates bagi rumah sakit. Pada tahap ini pasien diharapkan untuk menggunakan kembali pelayanan dan bersdia merekomendasikan pelayanan yang ada di Rumah sakit X kepada orang lain seperti keluarga dan teman (Surahmawati, 2015).

Penelitian yang sama telah dilakukan oleh Dewi (2016) tentang pengaruh kualitas pelayanan terhadap loyalitas pasien, menyimpulkan bahwa ada pengaruh antara kualitas pelayanan dengan loyalitas pasien. Demikian pula penelitian yang dilakukan oleh Gunawan (2011) menyatakan bahwa kualitas pelayanan memberika pengaruh secara signifikan terhadap loyalitas pasien di rumah sakit. Kedua penelitian tersebut sama-sama untuk mengetahui pengaruh kualitas pelayanan terhadap loyalitas pasien. Yang membedakan antara penelitian ini dengan penelitian sebelumnya adalah pada tingkatan loyalitas.
Penelitian ini melihat loyalitas pasien berada pada level apa.

Dari data kunjungan pasien rawat jalan elama 3 (tiga) tahun terakhir yaitu tahun 2016 - 2018, masalah yang dihadapi oleh Rumah Sakit $\mathrm{X}$ adalah penurunan jumlah kunjungan pasien rawat jalan di Rumah Sakit $X$ sebesar $10 \%$. Rumah Sakit $\mathrm{X}$ telah berupaya melakukan peningkatan kualitas pelayanan rawat jalan dengan harapan dapat meningkatkan loyalitas pasien terhadap pelayanan rawat jalan di Rumah Sakit X.

Berdasarkan hal di atas, peneliti tertarik untuk melakukan penelitian tentang pengaruh kualitas pelayanan rawat jalan terhadap tingkat loyalitas pasien di Rumah Sakit X. Penelitian ini bertujuan untuk mengetahui karakteristik pasien, kualitas pelayanan yang terdiri dari kualiats pelayanan dokter, pelayanan perawat, pelayanan petugas pendaftaran, dan kualitas sarana prasarana. Pengaruh antara kualitas pelayanan rawat jalan terhadap tingkat loyalitas pasien, serta meneliti pada level apa tingkat loyalitas pasien rawat jalan di Rumah Sakit X.

\section{METODE PENELITIAN}

Penelitian ini adalah penelitian deskriptif analitik. Rancang bangun penelitian ini adalah cross sectional yaitu variabel penelitian dilakukan pengukuran hanya sekali dalam satu waktu tertentu. Penelitian ini dilakukan di Rumah Sakit X pada bulan April sampai bulan Juni 2019. Populasi penelitian ini adalah pasien rawat jalan di Rumah Sakit X Surabaya. Besar sampel penelitian adalah 36 responden dengan teknik pengambilan sampel accidental sampling yang merupakan teknik penentuan sampel secara kebetulan. Teknik pengumpulan data menggunakan alat bantu lembar kuesioner.

Variabel penelitian ini meliputi karakteristik responden, kualitas pelayanan, dan tingkat loyalitas responden. Teknik analisis data menggunakan uji regresi linier berganda untuk mengetahui pengaruh kualitas pelayanan terhadap tingkat loyalitas pasien. Kualitas pelayanan sebagai variabel bebas dan tingkat loyalitas sebagai variabel terikat. Penilaian menggunakan kriteria apabila nilai mean $\geq 3,00$ berarti baik dan nilai mean < 3,00 berarti kurang baik. 


\section{HASIL DAN PEMBAHASAN}

\section{Karakteristik Responden}

Karakteristik responden dalam penelitian ini meliputi jenis kelamin, umur, pendidikan, pekerjaan, dan pendapatan keluarga responden.

Tabel 1. Karakteristik Responden Rawat Jalan Berdasarkan Jenis Kelamin, Umur, Pendidikan, Pekerjaan, dan Pendapatan Keluarga Responden di Rumah Sakit X

\begin{tabular}{|c|c|c|}
\hline Karakteristik & $\mathbf{n}$ & $\%$ \\
\hline \multicolumn{3}{|l|}{ Jenis Kelamin } \\
\hline Laki-laki & 7 & 19 \\
\hline Perempuan & 29 & 81 \\
\hline \multicolumn{3}{|l|}{ Umur } \\
\hline $17-35$ & 25 & 70 \\
\hline $36-45$ & 8 & 22 \\
\hline$>45$ & 3 & 8 \\
\hline \multicolumn{3}{|l|}{ Pendidikan } \\
\hline $\mathrm{SD} /$ sederajat & 1 & 2 \\
\hline SMP/ sederajat & 6 & 18 \\
\hline SMA/ sederajat & 20 & 55 \\
\hline D3 & 1 & 2 \\
\hline $\mathrm{S} 1 / \mathrm{S} 2$ & 8 & 23 \\
\hline \multicolumn{3}{|l|}{ Pekerjaan } \\
\hline Tidak bekerja & 7 & 19 \\
\hline PNS & 2 & 6 \\
\hline Pegawai swasta & 14 & 39 \\
\hline Lain-lain & 13 & 36 \\
\hline \multicolumn{3}{|l|}{ Pendapatan Keluarga } \\
\hline < UMR Surabaya & 16 & 45 \\
\hline 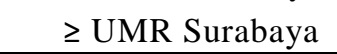 & 20 & 55 \\
\hline
\end{tabular}

Berdasarkan tabel 1 diketahui bahwa mayoritas responden adalah $81 \%$ responden berjenis kelamin perempuan, $70 \%$ berada pada kelompok umur 17 - 35 tahun sebanyak, 55\% memiliki jenjang pendidikan tingkat SMA/sederajat, 39\% bekerja sebagai pegawai swasta, $55 \%$ memiliki memiliki penghasilan keluarga $\geq$ UMR Surabaya.

\section{Kualitas Pelayanan Rawat Jalan}

Tabel 2. Kualitas Pelayanan Rawat Jalan di Rumah Sakit X

\begin{tabular}{lcc}
\hline \multicolumn{1}{c}{ Kualitas Pelayanan } & Mean & Keterangan \\
\hline Pelayanan Dokter & 3,04 & Baik \\
Pelayanan Perawat & 3,08 & Baik \\
Pelayanan Petugas & 3,05 & Baik \\
$\begin{array}{l}\text { Pendaftaran } \\
\text { Sarana Prasarana }\end{array}$ & 2,83 & Kurang Baik \\
\hline
\end{tabular}

Berdasarkan tabel 2 diketahui bahwa kualitas pelayanan dokter, kualitas pelayanan perawat, dan kualitas pelayanan petugas pendaftaran sudah baik karena mendapat nilai mean lebih dari 3,00. Sedangkan yang terkait dengan kualitas sarana prasarana yang tersedia di pelayanan rawat jalan Rumah Sakit X dinilai masih kurang baik dengan nilai mean kurang dari 3,00 .

\section{Tingkat Loyalitas}

Tabel 3. Tingkat Loyalitas Pasien Rawat Jalan di Rumah Sakit X

\begin{tabular}{lcc}
\hline \multicolumn{1}{c}{ Loyalitas } & Mean & Keterangan \\
\hline $\begin{array}{l}\text { Kesediaan } \\
\text { Menggunakan kembali }\end{array}$ & 3,06 & Loyal \\
$\begin{array}{l}\text { Kesediaan } \\
\text { merekomendasikan } \\
\text { kepada orang lain } \\
\text { (advocacy) }\end{array}$ & 2,86 & $\begin{array}{c}\text { Kurang } \\
\text { Loyal }\end{array}$ \\
\hline
\end{tabular}

Berdasarkan tabel 3 diketahui bahwa tingkat loyalitas pasien masih pada level kesediaan untuk menggunakan kembali pelayanan rawat jalan di Rumah Sakit X. loyalitas belum sampai level advocacy yaitu pasien masih belum bersedia untuk merekomendasikan pelayanan Rumah Sakit X kepada orang lain seperti keluarga/kerabat dan kolega.

\section{Hasil Uji Pengaruh antara Kualitas Pelayanan terhadap Tingkat Loyalitas}

Uji pengaruh antara kualitas pelayanan terhadap tingkat loyalitas menggunajan uji regresi linear berganda.

Tabel 4. Hasil Uji Regresi Linier Berganda Kualitas Pelayanan Terhadap Tingkat Loyalitas

\begin{tabular}{lcc}
\hline \multicolumn{1}{c}{$\begin{array}{c}\text { Kualitas } \\
\text { Pelayanan }\end{array}$} & Signifikansi & Keterangan \\
\hline $\begin{array}{l}\text { Pelayanan Dokter } \\
\text { Pelayanan Perawat }\end{array}$ & 0,000 & $\begin{array}{c}\text { Berpengaruh } \\
\text { Tidak } \\
\text { Berpengaruh } \\
\text { Berpengaruh }\end{array}$ \\
$\begin{array}{l}\text { Pelayanan Petugas } \\
\text { Pendaftaran }\end{array}$ & 0,00 & $\begin{array}{c}\text { Tidak } \\
\text { Sarana Prasarana }\end{array}$ \\
\begin{tabular}{l} 
Kualitas pelayanan \\
\multicolumn{2}{c}{ Berdasarkan tabel 4 diketahui bahwa } \\
Berpengaruh
\end{tabular} \\
$\begin{array}{l}\text { kualitas pelayanan yang memiliki pengaruh } \\
\text { terhadap tingkat loyalitas pasien adalah }\end{array}$
\end{tabular}


kualitas pelayanan dokter dan kualitas pelayanan petugas pendaftaran dengan nilai signifikansi $=0,000$. Sedangkan kualitas pelayanan perawat dan kualitas sarana prasarana tidak berpengaruh terhadap tingkat loyalitas pasien. Secara keseluruhan kualitas pelayanan rumah sakit memiliki pengaruh terhadap tingkat loyalitas pasien dengan nilai signifikansi 0,000 .

\section{Pembahasan}

Berdasarkan variabel karakteristik responden diketahui sebagian besar responden Rumah Sakit X berjenis kelamin perempuan dan berusia antara 17 - 35 tahun. Hal ini sesuai dengan teori yang disampaikan oleh Kotler \& Keller (2008) bahwa perempuan lebih sering memanfaatkan pelayanan kesehatan dibandingkan laki-laki. Pasien dalam kelompok umur muda memiliki kecenderungan yang tinggi untuk membanding-bandingkan kualitas pelayanan dan berpindah ke rumah sakit lain.

Pendidikan mempengaruhi pengetahuan pasien dalam mencari pelayanan kesehatan yang lebih berkualitas. Hal ini sesuai dengan hasil penelitian menunjukkan mayoritas pasien Rumah Sakit X memiliki pendidikan menengah (SMA/sederajat) dan tinggi (S1/S2). Berdasarkan pekerjaan dan penghasilan diketahui bahwa responden di Rumah Sakit X sebagian besar bekerja sebagai pegawai swasta dan telah memiliki penghasilan $\geq$ UMR di Kota Surabaya.

Berdasarkan variabel kualitas pelayanan menunjukkan bahwa kualitas pelayanan dokter, perawat, dan petugas pendaftaran yang berkaitan dengan ketrampilan, kehandalan, ketelitian, ketepatan waktu pelayanan, dan komunikasi petugas selama memberikan pelayanan sudah baik dengan nilai mean $\geq$ 3,00 . Kualitas sarana prasarana yang ada di Rumah Sakit $\mathrm{X}$ dinilai kurang baik dengan mean $<3,00$. Kualitas sarana prasarana yang dinilai berkaitan dengan kebersihan lingkungan rumah sakit, kemudahan dan keamanan parkir, kebersihan dan kenyamanan ruang tunggu, kebersihan dan kenyamanan ruang pemeriksaan dokter, dan kebersihan kamar mandi. Sesuai hasil penelitian Supartiningsih (2017) bahwa tingkat kualitas sarana prasarana rumah sakit dapat meningkatkan kepuasan pasien. Kepuasan pasien memberikan efek pada pasien untuk menggunakan kembali pelayanan rumah sakit. Pasien berharap pihak
Rumah Sakit $\mathrm{X}$ lebih meningkatkan kebersihan, kerapian, dan kenyamanan sarana prasaran rumah sakit.

Berdasarkan teori loyalitas bahwa loyalitas pasien ada beberapa tingkatan yaitu ACURA (Acquisition, Cross Selling, Up Selling, Retention, and Advocacy. Tingkatan loyalitas yang paling tinggi adalah advocacy (Kotler \& Keller, 2008). Hasil penelitian terkait tingkat loyalitas pasien diketahui bahwa tingkat loyalitas pasien di Rumah sakit X berada pada tingkat kesediaan pasien untuk membeli atau menggunakan kembali pelayanan yang ada di Rumah Sakit X dengan nilai mean 3,06. Tingkat loyalitas pasien belum sampai pada tingkat advocacy yaitu pasien masih belum bersedia merekomendasikan pelayanan Rumah Sakit X kepada keluarga maupun teman dengan nilai mean 2,83. Hal ini harus menjadi pertimbangan bagi rumah sakit $X$ untuk melakukan peningkatan kualitas pelayanan untuk mencapai tingkat loyalitas pasien menjadi advocacy Hurriyati (2010). Tingkat loyalitas advocacy menunjukkan bahwa pasien memiliki ikatan yang kuat terhadap pelayanan Rumah sakit X. Pasien tingkat advocacy tidak mudah berpindah ke pelayanan rumah sakit lain (Hurriyati, 2010).

Berdasarkan hasil uji regresi linear berganda diketahui bahwa yang mempengaruhi tingkat loyalitas pasien Rumah Sakit X adalah kualitas pelayanan dokter dan kualitas pelayanan petugas pendaftaran dalam memberi pelayanan rawat jalan dengan nilai signifikansi 0,000 . Sedangkan kualitas pelayanan perawat dan sarana prasarana tidak mempengaruhi tingkat loyalitas pasien Rumah Sakit X. Hasil ini sesuai dengan penelitian yang dilakukan Fitri \& Ainy (2016) bahwa yang berhubungan dengan loyalitas pasien rawat jalan adalah interaksi petugas dalam memberikan pelayanan pasien rawat jalan. Sedangkan kemanan dan kenyamanan rumah sakit tidak memiliki hubungan dengan loyalitas pasien rawat jalan.

Kualitas pelayanan secara keseluruhan berpengaruh secara signifikan terhadap tingkat loyalitas pasien di rumah sakit dengan nilai signifikansi 0,000 . Hal ini sesuai dengan hasil penelitian yang dilakukan oleh Dewi (2016) dan Gunawan \& Djati (2011) bahwa kualitas pelayanan memiliki pengaruh yang signifikan terhadap loyalitas pasien.

Penelitian ini juga mendukung hasil penelitian yang dilakukan Hidayat (2016) dan Utami (2019) tentang pengaruh kualitas pelayanan terhadap loyalitas pasien bahwa 
kualitas pelayanan memiliki pengaruh positif terhadap loyalitas pasien. Rumah Sakit X harus meningkatkan kualitas pelayanan untuk meningkatkan tingkat loyalitas pasien.Tingkat loyalitas yang diharapkan rumah sakit adalah pasien memiliki keinginan yang kuat untuk melakukan pembelian ulang pelayanan di Rumah Sakit $X$ serta keinginan merekomendasikan pelayanan di Rumah Sakit $\mathrm{X}$ kepada orang lain sebagai advocacy rumah sakit.

\section{KESIMPULAN DAN SARAN}

\section{Kesimpulan}

Penelitian ini menyimpulkan bahwa kualitas pelayanan dokter, perawat, dan petugas pendaftarandi Rumah Sakit X sudah baik sedangkan kualitas sarana prasarana masih dinilai kurang baik oleh responden. Berdasarkan hasil uji regresi linear berganda

\section{REFERENSI}

Dewi, R. R., (2016). Pengaruh Kualitas Pelayanan Terhadap Loyalitas Pasien Pengguna BPJS dengan Kepuasan Pasien sebagai Variabel Intervening. Daya Saing Jurnal Ekonomi Manajemen Sumber Daya, 18 (2), 146-156.

Fitri, A., N. \& Ainy, A., (2016). Hubungan Kualitas Pelayanan dengan Loyalitas Pasien di Istalasi Rawat Jalan Rumah Sakit Khusus Mata Provinsi Sumatera Selatan. Jurnal Ilmu Kesehatan Masyarakat, 7 (1), 22-31

Gunawan, K. \& Djati, S. P., (2011). Kualitas Layanan dan Loyalitas Pasien (Studi pada Rumah Sakit Umum Swasta di Kota Singaraja-Bali). Jurnal Manajemen dan Kewirausahaan, 13 (1), 32-39.

Hidayat, B. T., Arifin, R. \& Hufron, M., (2016). Pengaruh Kualitas Pelayanan Terhadap Loyalitas Pasien Rawat Inap RSUD Kanjuruhan Kepanjen dengan Kepuasan sebagai Variabel Intervening. e-Jurnal Riset Manajemen Prodi Manajemen, 9 (2), 3545.

Hurriyati, R., (2010). Bauran Pemasarandan Loyalitas Konsumen. Bandung: Aklfabeta. bahwa kualitas pelayanan dokter dan petugas pendaftaran berpengaruh terhadap tingkat loyalitas pasien. Kualitas pelayanan perawat dan sarana prasarana tidak berpengaruh terhadap tingkat loyalitas pasien. Sedangkan secara keseluruhan bahwa kualitas pelayanan rawat jalan berpengaruh terhadap tingkat loyalitas pasien. Tingkat loyalitas pasien di Rumah Sakit X masih berada pada tingkat kesediaan menggunakan kembali, belum sampai pada tingkatan advocacy.

\section{Saran}

Diharapkan pihak Rumah Sakit X terus meningkatkan kualitas pelayan. Rumah Sakit X diharapkan segera dapat memperbaiki kualitas sarana prasarana rumah sakit karena masih dianggap kurang memadai dalam menunjang pelayanan bagi pasien.

Kotler, P. \& Keller, K. L., (2008). Marketing Management Terjemahan. Ketiga Belas ed. Jakarta: Penerbit Erlangga.

Mudjid, R., A., Gobel, F. A. \& Burhanuddin, N., (2018). Pengaruh Kualitas Pelayanan Terhadap Kepuasan dan Kepercayaan Pasien di Puskesmas Paccerakkang Kota Makasar. Window of Health Jurnal Kesehatan, 1 (3), 186-196.

Supartiningsih, S., (2017). Kualitas Pelayanan Kepuasan Pasien Rumah Sakit :Kasus Pada Pasien Rawat Jalan. Jurnal Medicoeticolegal dan Manajemen Rumah Sakit, 6 (1), 9-15.

Surahmawati, (2015). Kualitas Pelayanan Kesehatan di Rumah Sakit Umum Daerah Barru (Kasus Pelayanan Rawat Jalan Pasien Pengguna Asuransi Kesehatan). Al Sihah Public Health Science Journal, 7 (1), 26-40.

Tjiptono, F., (2011). Pemasaran Jasa. Yogyakarta: Bayumedia Publishing.

Utami, N. R. B., (2019). Pengaruh Kualitas Layanan Pasien Rawat Inap Terhadap Loyalitas di Rumah Sakit Sekar Kamulyan denganKepuasan sebagai Variabel Mediasi. Jurnal Ekonomi Bisnis dan Akuntansi (JEBA), 21(1), 1-14. 